\title{
A combined clinical and histological assessment of survival of patients with Hodgkin's disease
}

\author{
R. M. CROSS AND F. W. P. DIXON \\ From the R.A.F. Central Medical Establishment, Kelvin House, London
}

\begin{abstract}
SYNOPSIS This paper reviews a series of 246 patients with Hodgkin's disease treated in the Royal Air Force Medical Service between 1940 and 1966. The clinical and histological staging of the disease in relation to the survival time is evaluated. The variation in the clinical patterns of the disease, together with the histological appearances in the affected glands, can be related to the patient's defence system. A most important clinical factor in assessing prognosis is considered to be the presence or absence of constitutional symptoms. The majority of the patients who had constitutional symptoms on presentation also had many glands involved. It was found in those patients who had no constitutional symptoms at the onset of the disease that there was little difference in survival time between those with glands involved in a single group or region and those with glands involved in many regions, whether above and/or below the diaphragm. Those patients with histologically well differentiated lesions showed a significantly higher survival rate than those in the histologically poorly differentiated groups.
\end{abstract}

Previous assessments of the prognosis of Hodgkin's disease have concentrated on two main factors, histological findings and clinical presentation.

\section{Histological Assessment}

Jackson and Parker (1944) separated Hodgkin's disease into paragranuloma, granuloma, and sarcoma. This showed reasonable agreement in that the cases of paragranuloma had a long survival and those of sarcoma a short one, but the prognostic value of the classification was somewhat limited, as the combined paragranuloma and sarcoma cases, on average, failed to represent more than $10 \%$ of the cases of Hodgkin's disease, whilst in the remainder, classified as granuloma, patients lived from one to 20 years. Lukes and Butler (1966) divided Hodgkin's disease into six types: lymphocytic and/or histiocytic diffuse, lymphocytic and/or histiocytic nodular, nodular sclerosis, mixed cellularity, diffuse fibrosis, and reticular types. They claimed a definite relationship between the different histological types and survival time.

At a symposium on the obstacles to the control of Hodgkin's disease in New York (1965) a new classification, based on that of Lukes and Butler, divided Hodgkin's disease into four groups: lymReceived for publication 30 September 1970. phocytic predominance, nodular sclerosis, mixed cellularity, and lymphocytic depletion.

Using a classification based on different histological criteria, Cross (1969) claimed an excellent correlation between the histologically determined types and survival time. The basis of the classification was the division of Hodgkin's disease into three groups, namely, reticular, histiocytic, and nodular sclerosis, depending on the presence or absence of epithelioid histiocytes or nodular formation of the fibrous tissue. Each group was subclassified into well and poorly differentiated types. Survival figures showed that the well differentiated types in each group had a good prognosis, whereas the poorly differentiated types had a bad one.

\section{Clinical Assessment}

Peters (1950) considered that 'although the histological picture was necessary for proof of diagnosis, it acted as an aid only in establishing the prognosis, but it was not as conclusive as the clinical findings demonstrated by the extent of lymph node involvement at first presentation'. She produced a clinical classification which divided Hodgkin's disease into three stages (Table I). Peters and Middlemiss (1958) modified the 1950 clinical classification to include the presence or absence of constitutional 


\begin{tabular}{ll}
\hline Stage & Area of Involvement \\
\hline I & $\begin{array}{c}\text { Single node region or single lesion elsewhere } \\
\text { in the body } \\
\text { Two or more proximal lymph node regions } \\
\text { of either the upper or lower trunk } \\
\text { Two or more lymph node regions of both } \\
\text { upper and lower trunk }\end{array}$ \\
\hline
\end{tabular}

Table I Clinical classification according to extent of involvement on admission (Peters, 1950)

symptoms in stage II. They concluded that the most important single factor influencing the prognosis and ultimate survival time of a case of Hodgkin's disease was the extent of lymph gland involvement when treatment was begun. The necessity for a standardized classification was once more emphasized at the Rye symposium (1965). The following clinical criteria for staging Hogdkin's disease were agreed to by the committee and approved by the members of that conference (Table II).

\begin{tabular}{ll}
\hline Stage $^{1}$ & Criteria \\
\hline I & $\begin{array}{l}\text { Disease limited to one anatomical region or to two } \\
\text { contiguous anatomical regions on the same side of the } \\
\text { diaphragm }\end{array}$ \\
II & $\begin{array}{l}\text { Disease in more than two contiguous regions or in two } \\
\text { non-contiguous regions on the same side of the dia- } \\
\text { phragm }\end{array}$ \\
Disease on both sides of the diaphragm but limited to \\
involvement of the lymph nodes, spleen, and Waldeyer's \\
ring \\
Involvement of the bone marrow, lung parenchyma, \\
pleura, liver, bone, skin, kidneys, gastrointestinal tract, \\
or any tissue or organ in addition to lymph nodes, spleen, \\
or Waldeyer's ring
\end{tabular}

Table II Clinical classification at the Rye

Symposium (1965)

${ }^{2}$ Each stage is subdivided into two categories: $\mathbf{A}$, without systemic effects of the disease, and B, with systemic effects of the disease.

\section{Present Study}

The value of any classification of Hodgkin's disease is threefold: (1) as a means of assessing the probable clinical course of the disease; (2) to estimate survival time; and (3) to assist in planning lines of therapy.

\section{CLINICAL PATTERNS OF HODGKIN'S DISEASE} AND ASSOCIATED HISTOLOGY

There is considerable variation in the clinical pattern of Hodgkin's disease and these may be correlated with the survival times of the patient. We now propose to attempt to relate the various clinically definable patterns to the histologically determined diagnosis as already described (Cross, 1969). Thus, we found that patients who lived for eight or more years showed the histological patterns of reticular lymphocytic (paragranuloma), well
R. M. Cross and F. W. P. Dixon

differentiated histiocytic, and well differentiated nodular sclerosis types. The last two, for convenience, o were grouped together.

Long-term survivors (as defined above) were found to have a variety of histologically assessed lesions.

\section{Reticular lymphocytic (paragranuloma)}

Patients with this type of lesion presented with slow, painless enlargement of a single anatomical region, usually the neck, with involvement of one.or several glands, but other areas, such as the axilla $\overrightarrow{\vec{\omega}}$ or inguinal region, could be involved. Followingo a diagnostic biopsy the treatment was generallyo radiotherapy, and the patient remained free fromin symptoms for many years. With recurrences, biopsyor again showed, in most cases, a similar histologicaliw appearance. Eventually, however, in the majorityor over eight years, the disease changed clinically and은 further histological examination of a lymph glandshowed a well differentiated reticular type of lesion $; \subseteq$ death then followed within four years. Occasionally, even in the first relapse, the biopsied nodes showed, $\overrightarrow{0}$ histologically, features previously defined (Cross,,1969) as typical of a poorly differentiated reticulartype of lesion; in such cases, survival time was usually@ much shorter. It is possible that change to this type of pattern may account for some of the acute casese which gave a history of glandular enlargemento many years before but in whom no biopsy had been carried out.

\section{Well differentiated histiocytic and nodular sclerosis types}

In general, these patients showed slow clinicalo progression and only one had constitutional symp-o toms at the onset. In patients with such slow and? insidious onset, many presented initially withô multiple gland involvement. Thus, of 44 patients with histological lesions considered to be of theo histiocytic and nodular sclerosis groups, $31(70 \%)$ had many glands involved on presentation. Theo course of the illness in these patients was characteristic. Given appropriate treatment, usually radiotherapy, they remained well for about two years 0 and then relapsed, either at the original site or elsewhere. Treatment of recurrences of glandularo swelling was satisfactory and they were reasonablyo fit to carry on with their occupations. Recurrence and good response to therapy, in many cases every? two years, went on for many years, usually more than 0 eight, until finally they died from multiple lesionso with involvement of the spine, intercurrent infec-D tions, and histological appearances suggesting $\vec{\otimes}$ obliteration of the normal reticulo-endothelial $\frac{\varrho}{\sigma}$ system. 
In agreement with Lukes' (1963) and Hanson's (1964) findings, the frequency of mediastinal involvement in the nodular sclerosis cases was high (Table III). The incidence of mediastinal involvement on initial presentation in the well differentiated nodular sclerosis cases was about four times that of mediastinal involvement in the rest of the well differentiated types as a whole. This incidence was also higher than that of the patients who presented with constitutional symptoms in both well differentiated and poorly differentiated types other than nodular sclerosis. There appears, thus, to be a high predilection for mediastinal involvement in patients with the nodular sclerosis type of lesion. The reason for this is unknown.

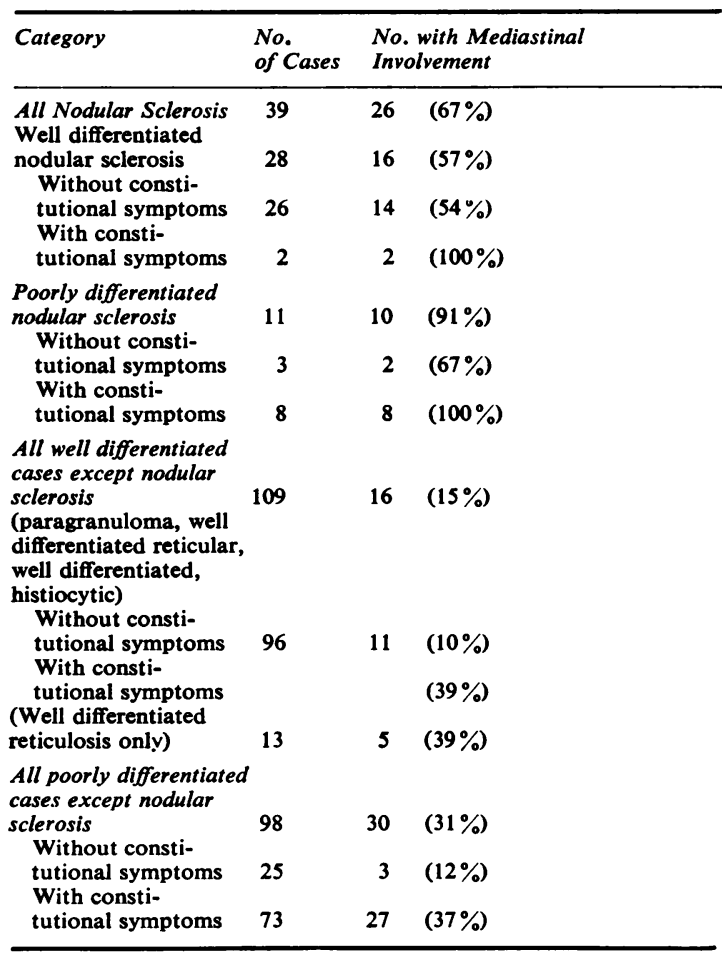

Table III Mediastinal involvement in Hodgkin's disease on presentation

\section{Patients running a moderate clinical course}

All the 71 patients found to behave clinically in this manner were originally diagnosed to have the well differentiated reticular type. Patients with this histologically defined type of disease usually presented with enlarged glands in the neck: $80 \%$ had involvement of the cervical region alone. Few had constitutional symptoms, $13(18 \%)$ out of 71 patients. Survival time ranged from four to eight years. Each recurrence became more disabling and eventually the disease became generalized with systemic symptoms. In repeated gland biopsies over the years the histological appearances showed a gradual change to a less differentiated type of picture.

\section{Patients with a short survival time}

Most of the patients who behaved in this manner were shown to have, on biopsy of the lymph glands, poorly differentiated types of all groups. The majority of these patients presented with constitutional symptoms. In 109 patients, in whom the initial histological diagnosis was of the poorly differentiated reticular, histiocytic, and nodular sclerosis groups, $81(74 \%)$ had constitutional symptoms at the onset. The disease seemed to be so sudden in onset and so progressive, that, by the time the patient first consulted the doctor, he was most likely to have enlarged glands widespread throughout the body. If only one gland or region was involved at presentation but was histologically diagnosed as poorly differentiated, then involvement of many glands usually soon followed within three months. Irrespective of the type of therapy used, immediate response was frequently dramatic. However, despite such excellent response to initial treatment, relapse soon occurred and, in general, death took place within four years and often under two years. Thus, our combined clinical and histological study indicated that a histopathological diagnosis of poorly differentiated reticular, histiocytic, or nodular sclerosis types of lesion carried with it a very bad prognosis.

\section{Assessment of Survival Time}

\section{CLINICAL ASSESSMENT ALONE}

Peters and Middlemiss (1958) stated that the 'survival rates and the incidence of recurrences reveal that there is at least a $35 \%$ error in clinical staging'. This was before the use of lymphangiography. With more experience regarding occult disease, Peters (1968) considered that out of 53 patients, who were classified as either stage I, IIA, or IIB, specialized procedures, such as lymphography, intravenous pyelograms, inferior venocavograms, bone marrow histology, and liver scan, showed that $29(55 \%)$ were wrongly classified.

All the patients in the present series were reviewed clinically within one month after presentation by two consultant surgeons, and only their assessment of the clinical findings were accepted.

For the purpose of estimating the survival times, 246 patients were available for the two-year assessment: 217 for the five years, 166 for the 10 years, 
and 121 for the 15 years. The distribution of our series of patients and the number of two, 10-, and 15-year survivors were classified according to the method of Peters and Middlemiss (1958) as seen in Table IV. It would appear from Table IV that the stage IIA group of patients has a better prognosis than the stage I group. The five-year survival rate (Table V) compares the Halton series with those of Peters (1950), Peters and Middlemiss (1958), and Lukes (1963). Although the five-year survival times in the stage I and II groups in our series are not as high as those reported by Peters (1950 and 1958) and Lukes (1963), the figures show a similar trend, and, as claimed by these authors, there is a relationship between the clinical stages and survival in that patients with a single region involved are seen to have a much better survival time than those in whom glands are involved both above and below the diaphragm.
As emphasized by the Rye (1965) conference, a most significant clinical finding is the presence of $\underline{\underline{O}}$ constitutional symptoms, indicating that the disease $\Rightarrow$ is widely disseminated throughout the body. These $\stackrel{\rho}{?}$ symptoms are fever, night sweats, and pruritus. 들 In our series (Table VI) there were 246 patients in the two-year survival assessment: 150 had no constitutional symptoms, whereas 96 patients had $\stackrel{\mathbb{2}}{2}$ constitutional symptoms on presentation. Of the 96 , only $33(34 \%)$ survived more than two years. In the five-year survival rate, out of 217 patients, $84(38 \%)$ had constitutional symptoms on presentation and none survived the five years.

If, therefore, the patients presenting with con- $\frac{7}{0}$ stitutional symptoms are excluded, the two- and is five-year survival times for the stages IA, IIA, and $\stackrel{\leftrightarrow}{\circ}$ IIIA (Rye) show that a patient with one region $\omega$ involved has not necessarily a better prognosis or that the patient with glands involved both above and $\frac{9}{2}$

\begin{tabular}{|c|c|c|c|c|c|c|c|c|c|c|c|c|}
\hline \multirow[t]{3}{*}{ Stage } & \multicolumn{12}{|c|}{ Survival Rate } \\
\hline & \multicolumn{3}{|c|}{ Two Years } & \multicolumn{3}{|c|}{ Five Years } & \multicolumn{3}{|c|}{ Ten Years } & \multicolumn{3}{|c|}{ Fifteen Years } \\
\hline & \multirow{2}{*}{$\begin{array}{c}\begin{array}{c}\text { No. of } \\
\text { Cases }\end{array} \\
82\end{array}$} & \multicolumn{2}{|c|}{$\begin{array}{l}\text { No. } \\
\text { Surviving }\end{array}$} & \multirow{2}{*}{$\frac{\begin{array}{l}\text { No. of } \\
\text { Cases }\end{array}}{71}$} & \multicolumn{2}{|c|}{$\begin{array}{l}\text { No. } \\
\text { Surviving }\end{array}$} & \multirow{2}{*}{$\begin{array}{c}\begin{array}{l}\text { No. of } \\
\text { Cases }\end{array} \\
54\end{array}$} & \multicolumn{2}{|c|}{$\begin{array}{l}\text { No. } \\
\text { Surviving }\end{array}$} & \multirow{2}{*}{$\begin{array}{l}\begin{array}{l}\text { No. of } \\
\text { Cases }\end{array} \\
38\end{array}$} & \multicolumn{2}{|c|}{$\begin{array}{l}\text { No. } \\
\text { Surviving }\end{array}$} \\
\hline I & & 62 & $(76 \%)$ & & 33 & $(46 \%)$ & & 11 & $(20 \%)$ & & 3 & $(8 \%)$ \\
\hline IIA & 70 & 62 & $(89 \%)$ & 63 & 38 & $(60 \%)$ & 47 & 13 & $(28 \%)$ & 35 & 5 & $(14 \%)$ \\
\hline IIB & 35 & 16 & $(45 \%)$ & 31 & - & - & 25 & - & 一 & 18 & - & - \\
\hline III & 59 & 26 & $(45 \%)$ & 52 & 13 & $(25 \%)$ & 40 & 2 & $(5 \%)$ & 30 & - & - \\
\hline $\begin{array}{l}\text { Totals all } \\
\text { stages }\end{array}$ & 246 & 166 & $(67 \%)$ & 217 & 84 & $(39 \%)$ & 166 & 26 & $(16 \%)$ & 121 & 8 & $(7 \%)$ \\
\hline
\end{tabular}

Table IV Survival rates of the Halton series using clinical classification of Peters and Middlemiss (1958)

\begin{tabular}{|c|c|c|c|c|c|c|c|c|c|c|c|c|}
\hline \multirow{2}{*}{$\begin{array}{l}\text { Clinical } \\
\text { Staging }\end{array}$} & \multicolumn{3}{|c|}{ Peters $(1950)$} & \multicolumn{3}{|c|}{ Peters (1958) } & \multicolumn{3}{|c|}{ Lukes (1963) } & \multicolumn{3}{|c|}{ Halton Series } \\
\hline & $\begin{array}{l}\text { No. of } \\
\text { Patients }\end{array}$ & $\begin{array}{l}\text { Alive at } \\
5 \text { Years }\end{array}$ & & $\begin{array}{l}\text { No. of } \\
\text { Patients }\end{array}$ & $\begin{array}{l}\text { Alive at } \\
5 \text { Years }\end{array}$ & & $\begin{array}{l}\text { No. of } \\
\text { Patients }\end{array}$ & $\begin{array}{l}\text { Alive at } \\
5 \text { Years }\end{array}$ & & $\begin{array}{l}\text { No. of } \\
\text { Patients }\end{array}$ & $\begin{array}{l}\text { Alive at } \\
5 \text { Years }\end{array}$ & \\
\hline $\begin{array}{l}\text { I } \\
\text { II } \\
\text { III }\end{array}$ & $\begin{array}{l}35 \\
32 \\
46\end{array}$ & $\begin{array}{r}31 \\
23 \\
4\end{array}$ & $\begin{array}{l}(88 \%) \\
(72 \%) \\
(9 \%)\end{array}$ & $\begin{array}{l}60 \\
70 \\
91\end{array}$ & $\begin{array}{l}43 \\
39 \\
14\end{array}$ & $\begin{array}{l}(71 \%) \\
(56 \%) \\
(15 \%)\end{array}$ & $\begin{array}{l}142 \\
127 \\
108\end{array}$ & $\begin{array}{r}100 \\
38 \\
13\end{array}$ & $\begin{array}{l}(70 \%) \\
(30 \%) \\
(13 \%)\end{array}$ & $\begin{array}{l}71 \\
94 \\
52\end{array}$ & $\begin{array}{l}33 \\
38 \\
13\end{array}$ & $\begin{array}{l}(46 \%) \\
(40 \%) \\
(25 \%)\end{array}$ \\
\hline
\end{tabular}

Table V Relationship between clinical staging and five-year survival rate

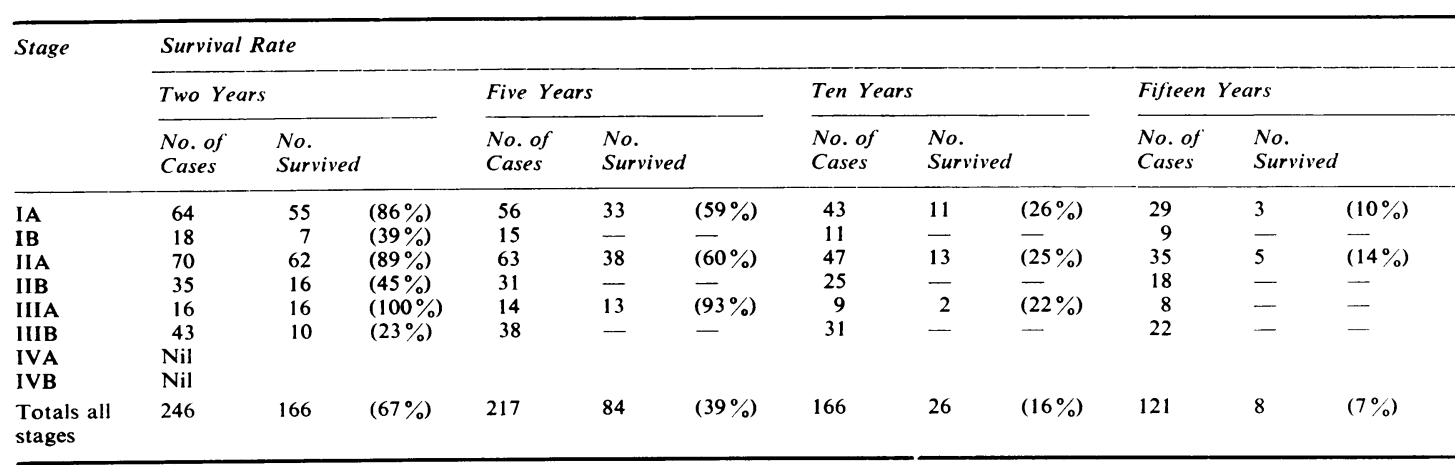

Table VI Two, five, 10, and 15-year survival rates of the Halton series using the Rye (1965) clinical classification $A$ (without) and $B$ (with constitutional symptoms) 
below the diaphragm. The more favourable survival times in those patients who had many regions involved at presentation, but in whom there were no constitutional symptoms, was due to the fact that the majority of the patients with well differentiated nodular sclerosis tended to present with multiple gland involvement (18 out of 22 cases) and the five-year survival rate in such patients was excellent.

SURVIVAL TIME CORRELATED WITH HISTOLOGICAL ASSESSMENT ALONE

The proportions of the histologically defined types have varied in reported series. Some series may have had more 'benign' cases, such as paragranuloma, whereas, in others, there may have been more of the histologically defined poorly differentiated cases. The degree of error in the histological definition and even in diagnosis is also a vital factor. Cases diagnosed wrongly as paragranuloma instead of reactive hyperplasia increase the numbers of long-term survivors. Symmers (1968) emphasized the possible errors in diagnosis when he reported a 'series of 600 cases of lymphadenopathy in which an initial diagnosis of Hodgkin's disease was reviewed in a reference laboratory, but this interpretation was confirmed in only 317 cases (53\%)'.
SURVIVAL TIME CORRELATED WITH BOTH CLINICAL AND HISTOLOGICAL FINDINGS The presence of constitutional symptoms was related to the different histological types (Table VII). None of the patients with the reticular lymphocytic (paragranuloma) type of lesion had constitutional symptoms, and the survival rate for five years was $100 \%$; in patients with well differentiated histiocytic lesions none had constitutional symptoms, and in those with well differentiated nodular sclerosis lesions only one patient had constitutional symptoms. The five-year survival rate in both these groups was $100 \%$ and $91 \%$ respectively. Patients with poorly differentiated lesions in all groups showed a high incidence of constitutional symptoms. Of the 96 patients with poorly differentiated lesions available for the five-year survival assessment, 70 $(75 \%)$ had constitutional symptoms and none survived five years.

The combination of a single gland and absence of constitutional symptoms at onset in no way guaranteed a good prognosis (Table VIII). Of 109 patients classified histologically as poorly differentiated types, $30(27 \%)$ had one gland only involved at presentation. Of these, 15 had constitutional symptoms and the median survival time was 8

\begin{tabular}{|c|c|c|c|c|c|}
\hline \multirow[t]{2}{*}{ Histological Grading } & \multicolumn{3}{|c|}{ No Constitutional Symptoms } & \multicolumn{2}{|c|}{ Constitutional Symptoms Present } \\
\hline & $\begin{array}{l}\text { No. of } \\
\text { Patients }\end{array}$ & $\begin{array}{l}\text { No. of } \\
\text { Survivors }\end{array}$ & & $\begin{array}{l}\text { No. of } \\
\text { Patients }\end{array}$ & $\begin{array}{l}\text { No. of } \\
\text { Survivors }\end{array}$ \\
\hline Reticular lymphocytic (paragranuloma) & 21 & 21 & $100 \%$ & Nil & - \\
\hline Reticular well differentiated & 49 & 28 & $57 \%$ & 13 & Nil \\
\hline Reticular pooriy differentiated & 21 & Nil & - & 59 & Nil \\
\hline Histiocytic well differentiated & 15 & 15 & $100 \%$ & Nil & - \\
\hline Histiocytic poorly differentiated & 2 & Nil & - & 6 & Nil \\
\hline Nodular sclerosis well differentiated & 22 & 20 & $91 \%$ & 1 & Nil \\
\hline Nodular sclerosis poorly differentiated & 3 & Nil & - & 5 & Nil \\
\hline
\end{tabular}

Table VII Relationship between histological grading, presence or absence of constitutional symptoms, and survival time for five years

\begin{tabular}{|c|c|c|c|c|c|}
\hline Histology & $\begin{array}{l}\text { Total } \\
\text { Number }\end{array}$ & $\begin{array}{l}\text { Number with One } \\
\text { Gland Only } \\
\text { Involved }\end{array}$ & Number & $\begin{array}{l}\text { Median } \\
\text { Survival } \\
\text { Time }\end{array}$ & Range \\
\hline $\begin{array}{l}\text { Poorly differentiated types } \\
\text { With constitutional } \\
\text { symptoms } \\
\text { No constitutional } \\
\text { symptoms }\end{array}$ & 109 & $30(27 \%)$ & $\begin{array}{l}15 \\
15\end{array}$ & $\begin{array}{l}8 \mathrm{mth} \\
1 \mathrm{yr} 7 \mathrm{mth}\end{array}$ & $\begin{array}{l}3 \mathrm{mth} \text { to } 3 \mathrm{yr} 5 \mathrm{mth} \\
5 \mathrm{mth} \text { to } 3 \mathrm{yr} 3 \mathrm{mth}\end{array}$ \\
\hline $\begin{array}{l}\text { Well differentiated types } \\
\text { With constitutional } \\
\text { symptoms }\end{array}$ & 137 & $51(37 \%)$ & 3 & $3 \mathrm{yr} 7 \mathrm{mth}$ & $\begin{array}{l}3 \text { yr } 3 \mathrm{mth} \text { to } \\
3 \mathrm{yr} 7 \mathrm{mth}\end{array}$ \\
\hline $\begin{array}{l}\text { No constitutional } \\
\text { symptoms }\end{array}$ & & & 48 & $6 \mathrm{yr}$ & $2 \mathrm{yr}$ to $21 \mathrm{yr}$ \\
\hline
\end{tabular}

Table VIII Relationship between histological type, presence or absence of constitutional symptoms, and survival time in patients with one gland only involved at presentation 
months (range $3 \mathrm{mth}$ to $3 \mathrm{yr} 5 \mathrm{mth}$ ). Of the 15 who did not have constitutional symptoms, the median survival time was $1 \mathrm{yr} 7 \mathrm{mth}$ (range $5 \mathrm{mth}$ to $3 \mathrm{yr}$ $3 \mathrm{mth}$ ). Of 137 patients classified histologically as well differentiated types, $51(37 \%)$ had one gland only involved at presentation. Of these, three had constitutional symptoms and the median survival time was 3 yr $7 \mathrm{mth}$ (range $3 \mathrm{yr} 3 \mathrm{mth}$ to 3 yr 7 mth). Of the 48 patients who had no constitutional symptoms, the median survival time was $6 \mathrm{yr}$ (range 2 yr to $21 \mathrm{yr}$ ). In patients, therefore, who have no constitutional symptoms on presentation, yet, have a poorly differentiated histological pattern in the lymph gland biopsy, it is considered advisable to rely more on the histological appearances for prognosis than on the clinical assessment.

\section{Clinical and Histological Assessment Applied to Treatment}

Our experience from the clinical studies of 246 patients with Hodgkin's disease, combined with information in the literature, indicates that in the treatment of any form of Hodgkin's disease it seems necessary to minimize further damage to the reticuloendothelial system than has already been produced by the disease, for in the terminal stages of any type of Hodgkin's disease intercurrent infections commonly prevail. Aisenberg (1968) considered it 'probable that the defect in cellular immunity in Hodgkin's disease contributes significantly to the susceptibility to fungal and other infections', but it is not known how much this defect is due to the disease itself, to treatment, or to a combination of both.

In planning treatment, the important factors are: the presence or absence of constitutional symptoms; the extent of the disease; the histological grading, which is also considered to provide some indication of the host resistance.

In general, the treatment of Hodgkin's disease includes surgery, radiotherapy, and cytotoxic drugs.

\section{Surgical Therapy}

Molander and Pack (1968) considered that radical excision of affected and related nodes may be the initial treatment of choice in clearly defined unifocal Hodgkin's disease, although only in a few selected patients. In the present series, however, radical surgery was not attempted in any patient as primary treatment.

\section{Radiotherapy}

Radiotherapy was the initial form of treatment for most of our patients. However, in recent years it has been our practice to treat those presenting with severe constitutional symptoms in the first instance with cytotoxins. Treatment by radiotherapy to the initial site or sites alone was practised until the late 1950 s after which time those patients who presented with involvement of one or both sides of the neck were given in addition prophylactic irradiation to the mediastinum. In general, the patients with paragranuloma involving cervical nodes had initial deep $x$-ray therapy to these sites alone.

Although Peters (1958) stated that the radiotherapist was not anxious to irradiate more normal tissue than was necessary, Kaplan and Rosenberg (1966) and Peters (1968) advised that the 'extended field method of radical radiotherapy be carried out in all patients with Hodgkin's disease'. This entailed giving a tumoricidal dose of irradiation to the whole lymphatic area whether above or below the diaphragm if the patient had stage I or II disease (Peters and Middlemiss or Rye classification). Kaplan and Rosenberg (1966) and Peters (1968) claimed an improvement in survival rate with such extended irradiation schedules. However, the figures quoted refer to comparisons of survival times of patients classified by clinical staging alone and not by clinical and histological methods of grading the disease at the onset.

\section{Chemotherapy}

In this series, the drugs used have been Degranol (mannomustine), $\mathrm{HN}_{2}$ (nitrogen mustard), Velbe, Leukeran, Cyclophosphamide, and Natulan (methyl hydrazine). In those patients, in our series, presenting without constitutional symptoms the histological grading was, in the majority, either paragranuloma or the well differentiated reticular, histiocytic, or nodular sclerosis type previously described (Cross, 1969). Initially, treatment was by radiotherapy, but, in the event of recurrence of the disease at the original site or sites, consideration was given to further irradiation and/or cytotoxic therapy. In the patients with severe constitutional symptoms on presentation, the majority were histologically poorly differentiated. This group consisted, on the whole, of patients who were acutely ill and they were treated initially with cytotoxic drugs only. Our practice has been to give nitrogen mustard to a total dose of $20-30 \mathrm{mg}$ of $\mathrm{HN}_{2}$. If and when the constitutional symptoms resolved under such treatment, radiotherapy was considered. 
In patients with recurrence of any histological type of the disease who had constitutional symptoms so severe as to be considered unfit for radiotherapy, it was decided to avoid, when possible, long periods of maintenance therapy with cytotoxic drugs, because of the probable further damage to the reticuloendothelial system. Instead, short-term, but massive therapy with cyclophosphamide was given. By this is meant the administration of $5 \mathrm{~g}$ given over a period of five to six days together with, when necessary, barrier nursing (Binns and Southall, 1970).

A feature in cytotoxic therapy is the fact that one patient may respond to a particular drug, whilst another, with an apparently identical clinical and histological classification, will be unaffected by that compound but may respond to some other cytotoxin. A patient may, at some stage, fail to respond to a drug which had previously appeared to control the disease, but the administration of a different cytotoxin may then result in a further remission of symptoms. The steroids are widely considered by clinicians to have no effect on the course of Hodgkin's disease. They may, however, have a place in treatment, particularly in those patients with associated pruritus and demonstrable autoimmune haemolytic anaemia.

We emphasize that treatment should always be tempered by consideration of its depressing affects on the reticuloendothelial system. Perhaps the extended field technique and the 'mantle' method of radiotherapy should be confined to those patients showing a poorly differentiated histology in the biopsied node. Similarly, as regards cytotoxic therapy, the prolonged use of many of these compounds as maintenance therapy is considered by us to be cumulatively damaging to the reticuloendothelial system.

\section{General Observation on Prognosis in Hodgkin's Disease}

A satisfactory explanation has not yet been given as to why some patients with Hodgkin's disease present with single or multiple gland involvement, or why some patients die within six months while others survive for 20 years or more. We agree with the views of Lukes and Butler that the variations in the histological patterns in Hodgkin's disease are expressions of degrees of effectiveness of the host's defence against this malignant neoplasm, but, in addition, we consider that the varied clinical patterns can also be correlated with host response.

In our opinion, there would appear to be two main lines of defence against the extension of Hodgkin's disease.
DEFENCE ASSOCIATED WITH IMMUNE RESPONSE

To account for single or multiple gland involvement at the onset of the illness, it is suggested that there exists a natural barrier or immune process which protects individuals against the induction of Hodgkin's disease. Some unknown agent, viral or otherwise, may gain entry to the body, perhaps most commonly through the upper respiratory tract, producing lesions in the cervical region, or through the gastrointestinal tract, producing intra-abdominal lesions. The barrier may be broken in one gland or region only, as in the lymphocytic reticular (paragranuloma) type where the immune defence is reasonably competent, or in several gland regions, as in the poorly differentiated types, where the immune defence is poor. In addition, it is possible that, once the barrier is broken and Hodgkin's type cells develop, they may spread either by the lymphatic system and/or possibly by the blood stream (Rappaport and Strum, 1970), when the limiting factor to metastatic foci would be the immune process. As the disease progressed the gradual elimination of the immune defences could be expected through destruction of the reticuloendothelial system. This may well account for the frequent findings at necropsy of multiple foci of Hodgkin's disease scattered throughout the body.

Lukes, Butler, and Hicks (1966) indicated that prolonged survival in Hodgkin's disease was associated with histological types manifested by lymphocytic proliferation, and this association emphasized again the importance of the lymphocyte in prognosis presented by Rosenthal (1936). These views on the importance of lymphocytic proliferation in the prognosis of Hodgkin's disease was shown in the better survival times of patients with well differentiated histological types of lesions in the involved lymph nodes (Cross, 1969).

SECONDARY DEFENCE OF FIBROSIS AND HISTIOCYTES

Examples from other fields of oncology indicate that the presence of large amounts of fibrous tissue in association with, for example, carcinoma of the breast, can be correlated with longer survival times. This suggests that 'fibrosis' has some 'protective' effects against the spread of carcinoma. It is submitted that this same reason may perhaps hold for Hodgkin's disease. Patients with histologically diagnosed nodular sclerosing fibrous types of lesions may have a better prognosis. Hadfield and Garrod (1943) emphasized that the phagocytic cells of the reticuloendothelial system were active in resisting the development and spread of any malignant growth. This could be taken to indicate that marked histio- 


\begin{tabular}{|c|c|c|c|c|c|c|c|c|c|}
\hline \multirow[t]{2}{*}{ Histological Type } & \multicolumn{3}{|c|}{ All Cases } & \multicolumn{3}{|c|}{ Single Region on Presentation } & \multicolumn{3}{|c|}{ Multiple Regions on Presentation } \\
\hline & No. & $\begin{array}{l}\text { Median } \\
\text { Survival } \\
\text { Time (yr) }\end{array}$ & $\begin{array}{l}\text { Range } \\
(y r)\end{array}$ & No. & $\begin{array}{l}\text { Median } \\
\text { Survival } \\
\text { Time }(y r)\end{array}$ & $\begin{array}{l}\text { Range } \\
(y r)\end{array}$ & No. & $\begin{array}{l}\text { Median } \\
\text { Survival } \\
\text { Time (yr) }\end{array}$ & $\begin{array}{l}\text { Range } \\
\text { (yr) }\end{array}$ \\
\hline $\begin{array}{l}\text { Reticular lymphocytic } \\
\text { (paragranuloma) }\end{array}$ & 22 & $9^{8 / 12}$ & 3 to 20 & $\stackrel{9}{(41 \%)}$ & $12 \% 12$ & 3 to 20 & $\begin{array}{l}13 \\
(49 \%)\end{array}$ & 10 & $5^{2 / 12}$ to 20 \\
\hline $\begin{array}{l}\text { Reticular well } \\
\text { differentiated }\end{array}$ & 71 & $4^{6 / 12}$ & $1^{1 /} 12$ to 8 & $\begin{array}{l}30 \\
(42 \%)\end{array}$ & $4 \% / 12$ & $2^{5 / 12}$ to 8 & $\begin{array}{c}41 \\
(58 \%)\end{array}$ & $4^{6 / 12}$ & $12 / 12$ to 8 \\
\hline $\begin{array}{l}\text { Histiocytic well } \\
\text { differentiated }\end{array}$ & 16 & $9^{1 / 12}$ & $34 / 12$ to 21 & $\begin{array}{c}8 \\
(50 \%)\end{array}$ & $10 \% 12$ & $5 \% / 12$ to 20 & $\begin{array}{c}8 \\
(50 \%)\end{array}$ & $7^{10 /} 12$ & $3^{3 / 12}$ to 14 \\
\hline $\begin{array}{l}\text { Nodular sclerosis well } \\
\text { differentiated }\end{array}$ & 28 & $7^{2 / 12}$ & $3^{8 i}{ }_{12}$ to 21 & $\begin{array}{l}5 \\
(18 \%)\end{array}$ & $7^{5 /} 12$ & $3^{7 / 12}$ to 18 & $\begin{array}{c}23 \\
(82 \%)\end{array}$ & $6^{11 / 12}$ & $3^{8 / 12}$ to 21 \\
\hline $\begin{array}{l}\text { All groups poorly } \\
\text { differentiated }\end{array}$ & 109 & $1^{1 / 12}$ & ${ }^{1 / 12}$ to $3^{8 / 12}$ & $\begin{array}{l}30 \\
(28 \%)\end{array}$ & $14 / 12$ & ${ }^{3 / 12}$ to $3^{5 / 12}$ & $\begin{array}{c}79 \\
(72 \%)\end{array}$ & 1 & ${ }^{1 / 12}$ to $3^{8 / 12}$ \\
\hline Total & 246 & $3^{3 / 12}$ & ${ }^{1 / 12}$ to 21 & 83 & $3^{7 / 12}$ & ${ }^{3 / 12}$ to 20 & 163 & $2^{10 /} 12$ & $1 / 12$ to 21 \\
\hline
\end{tabular}

Table IX Survival time related to histology and glandular regions involved

cytic differentiation in a Hodgkin's lesion may also imply a better prognosis by virtue of the very presence of so many well differentiated phagocytic cells. If the above two suggestions are valid, then it may be anticipated that patients with Hodgkin's disease who have a nodular sclerosis pattern or preponderance of histiocytes in the lymph nodes may survive longer, regardless of the extent of glandular involvement at the onset. Our figures (Table IX) indeed indicate that this is so; of the 28 patients with histologically defined well differentiated nodular sclerosis type, the outstanding clinical finding was the extent of multiple glandular involvement in more than one anatomical region on presentation. Despite this, however, the overall median survival time was 7 years, the range being $3 \mathrm{yr} 8 \mathrm{mth}$ to 21 years. The median survival time of the patients showing the well differentiated histiocytic type of lesion was $9 \mathrm{yr} 1 \mathrm{mth}$ (range $3 \mathrm{yr} 4 \mathrm{mth}$ to $21 \mathrm{yr}$ ).

\section{Conclusions}

In the majority of the patients in this series who had constitutional symptoms many glands were also affected. However, in the patients who had no constitutional symptoms, there was little difference n survival time between those in whom glands were initially involved in a single region or in many regions. The clinical extent of the disease, as represented by the numbers and site of involved glands on presentation, is, in our opinion, not as valuable in prognosis as the combined assessment of the histological grade and the presence or absence of constitutional symptoms.

As a result of our findings a modified clinical classification is proposed: Stage I, glandular involvement in one anatomical lymphatic region without constitutional symptoms; stage II, glandular involvement in more than one anatomical lymphatic region without constitutional symptoms; stage III, the presence of constitutional symptoms irrespective of the number of lymphatic regions involved.

We wish to thank the Director General of RAF Medical Services for permission to publish this paper. To Sir Stanford Cade we are deeply indebted for his advice over the years regarding the supervision and care of the great majority of these patients. Our grateful thanks go to $\mathrm{Mr}$ T. M. Prossor, Dr K. Newton, and Miss P. Wheatley, MBE, of the Radiotherapy Department, Westminster Hospital. Lastly we thank Miss Lindsay, Mrs Sears, Miss Anson, and Miss Davies for their work in the registry and in typing this article.

\section{References}

Aisenberg, A. C. (1968). Immunologic defeots. In Hodgkin's Disease, edited by D. W. Molander and G. T. Pack, p. 70. Thomas, Springfield, Illinois.

Binns, J. H., and Southall, A. C. (1970). Intensive cyclophosphamide therapy in advanced malignant disease. Practitioner, 204, 546-548.

Cross, R. M. (1969). Hodgkin's disease: histological classification and diagnosis. J. clin. Path., 22, 165-182.

Hadfield, G., and Garrod, L. P. (1942). Recent Advances in Pathology, 4th ed., p. 97. Churchill, London.

Hanson, T. A. S. (1964). Histological classifications and surviva in Hodgkin's disease-A study of 251 cases with special reference to nodular sclerosing Hodgkin's disease. Cancer (Philad.), 17, 1595-1603.

Jackson, $H$, Jr., and Parker, F. Jr. (1944a). Hodgkin's disease. I. General considerations. New Engl. J. Med., 230, 1-8.

Jackson, H., Jr., and Parker, F. Jr. (1944b). Hodgkin's disease, II Pathology, New Engl. J. Med., 231, 35-44.

Kaplan, H. S. (1966). Role of intensive radiotherapy in the management of Hodgkin's disease. Cancer (Philad.), 19, 356-367.

Kaplan, H. S., and Rosenberg, S. A. (1966). Extended-field radical radiotherapy in advanced Hodgkin's disease: Short term results of 2 randomized clinical trials. Cancer Res., 26, 12681276.

Lukes, R. J. (1963). Relationship of histologic features to clinical stages in Hodgkin's disease. Amer. J. Roentgenol., 90, 944-955.

Lukes, R. J., and Butler, J. J. (1966). The pathology and nomenclature of Hodgkin's disease. Cancer Res., 26, 1063-1081. 
Lukes, R. J., Butler, J. J., aod Hicks, E. B. (1966). Natural history of Hodgkin's disease as related to its pathologic picture. Cancer (Philad.), 19, 317-344.

Molander, D. W., and Pack, G. T. (1968). Treatment of Hodgkin's disease. In Hodgkin's Disease, edited by $\mathrm{D}$. W. Molander and G. T. Pack, p. 151. Thomas, Springfield, Illinois.

Peters, M. V. (1950). A study of survivals in Hodgkin's disease treated radiologically. Amer. J. Roentgenol., 63, 299-311.

Peters, M. V. (1966). Prophylactic treatment of adjacent areas in Hodgkin's disease. Cancer Res., 26, 1232-1243.

Peters, M. V., and Middlemiss, K. C. H. (1958). A study of Hodgkin's disease treated by irradiation. Amer. J. Roentgenol., 79, 114-121.

Rappaport, H., and Strum, S. B. (1970). Vascular invasion in Hodgkin's disease. Its incidence and relationship to spread. Cancer (Philad.), 25, 1304-1313.

Rosenthal, S. R. (1936). Significance of tissue lymphocytes in the prognosis of lymphogranulomatosis. Arch. Path., 21, 628-646.

Symmers, W. St. C. (1968). Survey of the eventual diagnosis in 600 cases referred for a second histological opinion after an initial biopsy diagnosis of Hodgkin's disease. J. clin. Path.: 21, 650653.

\section{The May 1971 Issue}

\section{THE MAY 1971 ISSUE CONTAINS THE FOLLOWING PAPERS}

Beyond the moon-some problems in space medicine BERNARD M. WAGNER

Bacteraemia in patients receiving human cadaveric renal transplants D. A. LEIGH

Streptococcal infection in a large general hospital R. FREEMAN

Preparation of antiviral sera for immunofluorescence on infected tissue culture SUSAN HERD AND KATHLEEN MACWILLIAM

Rapid diagnosis of respiratory syncytial virus infection in children by the immunofluorescent technique J.E. CRADOCK-WATSON, JOYCE MCQUILLIN, AND P. S. GARDNER

Evaluation of three methods using deoxyribonuclease production as a screening test for Serratia marcescens W. A. BLACK, R. HODGSON, AND ANN MCKECHNIE

Bacterial and fungal flora of seagull droppings in Jersey JOHN CRAGG AND YVONNE M. CLAYTON

A blue catalase screening test for pyuria and haematuria MAIR THOMAS AND GILLIAN BALDWIN

A laboratory study of spontaneous platelet aggregation I. FRIEDLANDER, I. J. Y. COOK, C. HAWKEY, AND C. SYMONS

The significance of folic acid, tissue iron stores, and tissue viability in determining iron uptake from serum by thyroid tissue slices W. M. BUCHANAN

Proposed recommendations for measurement of serum iron in human blood The International Committee for Standardization in Haematology
Porphyrin biosynthesis in the erythrocytes of patients with sideropenic anaemias O. GUTNIIAK, M. KOPEĆ, AND J. NIECZAJ

Breast involvement in Wegener's granulomatosis H. PAMBAKIAN AND J. R. TIGHE

The pathology of parietal pleural plaques G. HEFIN ROBERTS

An unusual form of renal disease associated with gout and hypertension W. VAN GOOR, C. J. KOOIKER, AND E. J. DORHOUT MEES

Two cases of scleroma in Iran K. ALAVI, E. коHOUT, AND W. DUTZ

The possible significance of $\operatorname{IgA}$ in abnormal cerebrospinal fluid NEELA K. SHETH

Badge of the President of the Association of Clinical Pathologists

\section{Technical methods}

An envelope system designed to facilitate safer transport and rapid identification of 'high risk' specimens in hospital laboratories JOHN D. CASH

Modification of the electrophoretic separation of lipoproteins on paper J. PYROVOLAKIS, J. HATZIOANNOU, AND C. GARDIKAS

\section{Present day practice}

Laboratory precision and diagnostic errors J. D. ACLAND AND S. LIPTON

Book reviews

Copies are still available and may be obtained from the PUBLISHING MANAGER, BRITISH MEDICAL ASSOCIATION, TAVISTOCK SQUARE, WC1H 9JR price $£ 1.05$ 